\title{
Normal and Abnormal Fetal Face
}

\author{
Israel Goldstein and Zeev Wiener \\ Rambam Health Care Campus, Haifa \\ Israel
}

\section{Introduction}

During the early stages of embryogenesis, genetic factors play the predominant role in the development of the fetal face. In later stages, environmental influences increase in importance. Facial malformation may be the result of chromosomal aberrations as well as teratogenic factors. Therefore, facial dysmorphism can provide important clues that suggest chromosomal or genetic abnormalities. The post-natal diagnosis of facial dysmorphism is a well-known pediatric diagnosis, primarily based on pattern diagnosis related to the appearance of one or a combination of facial features, such as low-set ears, hypohypertelorism, small orbits, micrognathia, retrognatia, and more. Some of these features are detectable prenatally (Benacerraf, 1998). More than 250 syndromes are associated with disproportional growth of abnormal features of the fetal face (Smith \& Jones, 1988).

\begin{tabular}{lll} 
Indication & $\mathbf{N}$ & $\%$ \\
\hline Other fetal anomalies detected by US & 118 & 52.8 \\
\hline Familial history of craniofacial malformations & 72 & 32.2 \\
\hline Maternal drug intake & 25 & 11.2 \\
\hline Fetal chromosomal aberrations & 8 & 3.6 \\
\hline Total & $\mathbf{2 2 3}$ & \\
\hline
\end{tabular}

Table 1. Indications for ultrasound examination of the fetal face (Pilu et al., 1986)

Sonographic assessment of the fetal face is part of the routine anatomic survey. Recently, three-dimensional ultrasound (3D) images of the fetus can be also obtained. However, twodimensional ultrasonographic images are more easily, rapidly, efficiently, and accurately obtained. Imaging of the fetal face is possible in most ultrasound examinations beyond 12 weeks of gestation.

This chapter describes normal structural development and the sonographic approach to evaluation of the fetal face. Clinical applications are discussed in relation to perinatal management.

\section{Fetal face profile}

Sonographic imaging of the fetal face can provide information for the antenatal diagnosis of fetuses with various congenital syndromes and chromosomal aberrations, many of which are known to be associated with facial malformations. Deviation from the normal 
proportions of the fetal face profile might be one of the 'soft sonographic signs' that can provide important clues that suggests congenital syndromes (Benacerraf, 1998).

Visualization of the curvature of the forehead is important to rule out a flat forehead, such as microcephaly, or bossing of the forehead, such as craniosynostosis (Goldstein et al., 1988). Visualization of the bridge of the nose could rule out Apert or Carpenter syndromes (Smith \& Jones, 1988). Visualization of normal prominent lips can rule out cleft lip (Benacerraf, 1998). Finally, a normal jaw appearance is important to rule out microganthia or prognathia (Sivan et al., 1997).

Evaluation of the fetal face structures is suggested on the coronal and mid-sagittal views. The fetal face profile appearance should be obtained, while an imaginary line is passed through the nasion (bridge of the nose) and the gnathion (lower protrusion of the chin). This imaginary line is vertical to the maxillary bone. In this view, the following structures can be identified: the bridge and tip of the nose, the philtrum (area between the nose and the upper lip), upper and lower lips, and chin (Goldstein et al., 2010).

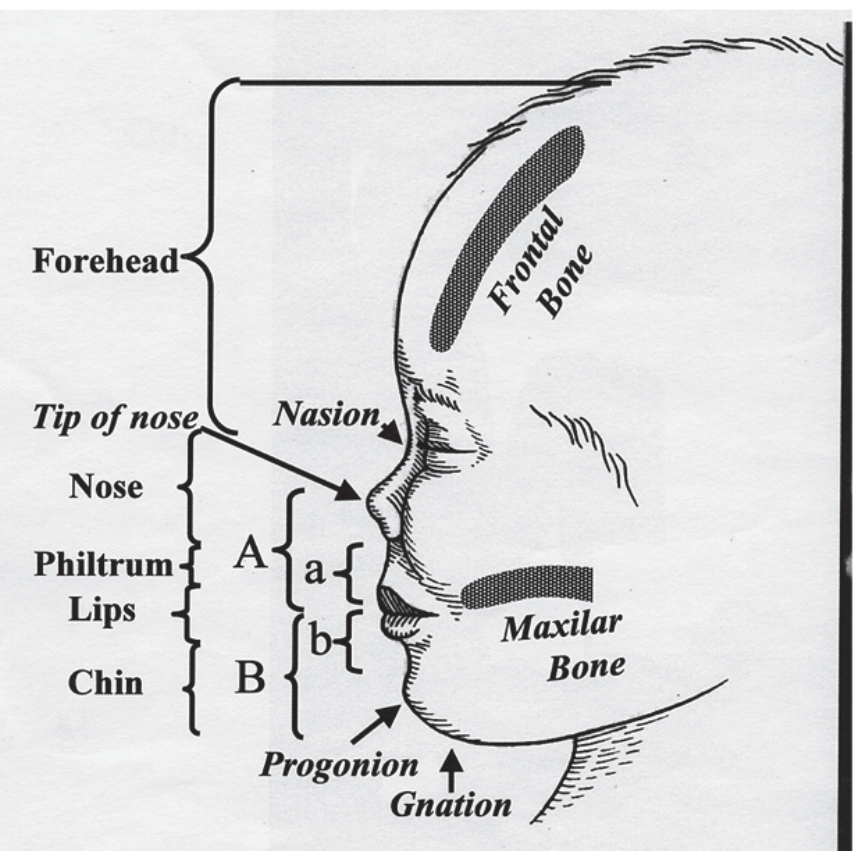

Fig. 1. A describes the distance from the tip of the nose to the mouth (line between the lips), $\mathbf{B}$ from the mouth to the chin, a describes the distances from the upper philtrum and the mouth, $\mathbf{b}$ from the mouth and the upper concavity of the chin.

The ratios between the following distances are independent of the gestational age and are almost constant: the distances between the tip of the nose and the mouth, and the distance from the mouth to the gnathion. In addition, a constant ratio was found between the upper philtrum and the mouth and from the mouth to the upper concavity of the chin (Goldstein et al., 2010). 

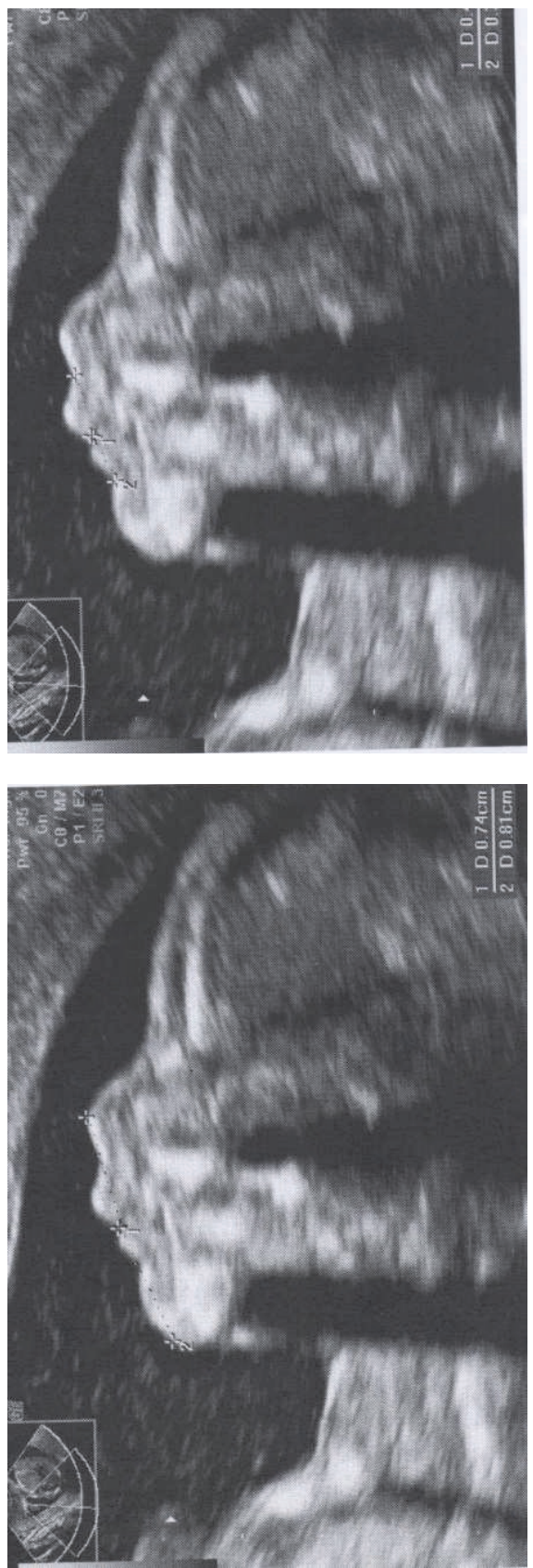

Fig. 2. Sonographic picture of the fetal face. Typical facial concavities and protrusions are presented. The calipers measured between the upper philtrum to the mouth (upper picture), and between the mouth to the chin (lower picture). 

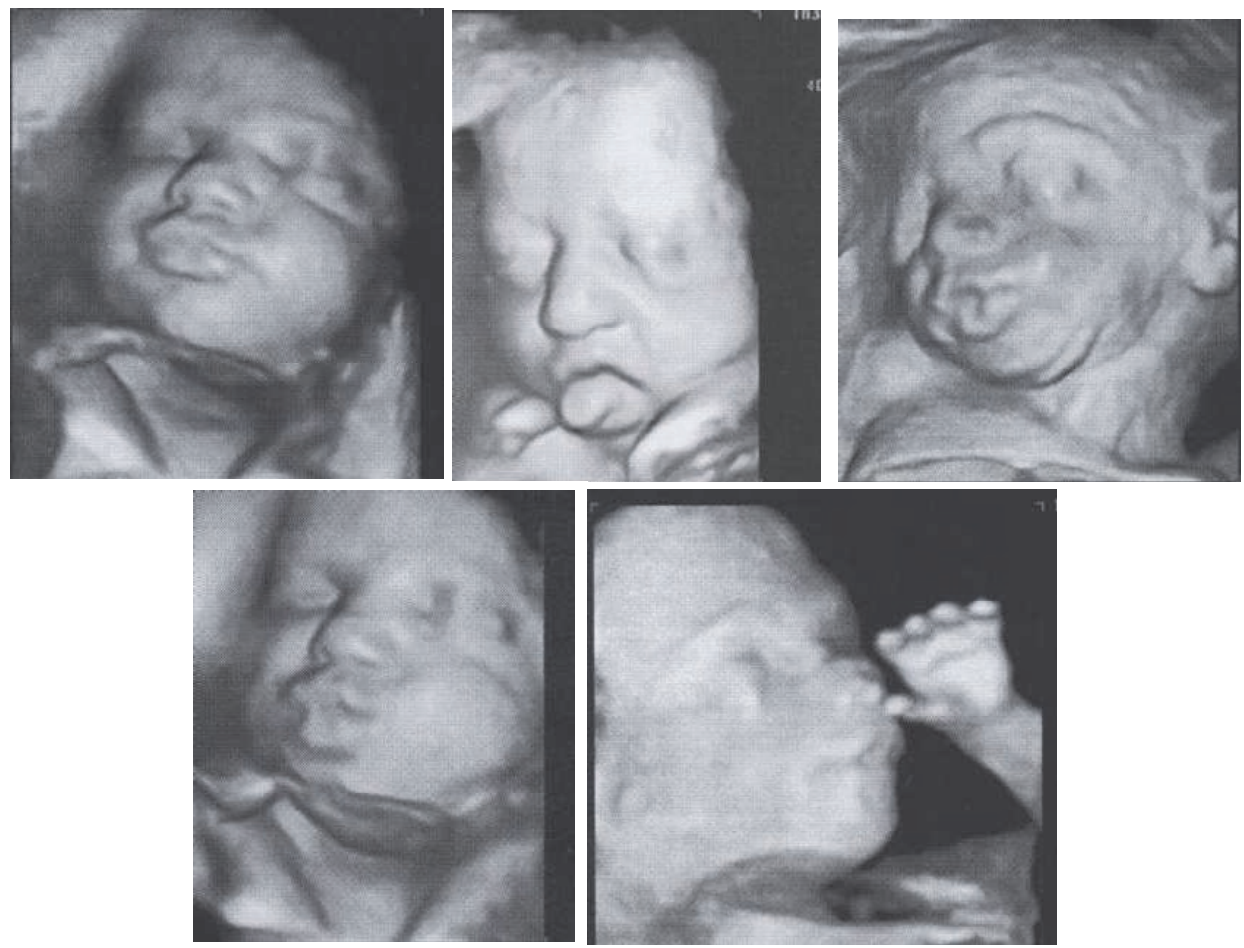

Fig. 3. 3D pictures of the fetal face. Mimics of face: a. kiss, b: open mouth and tongue, c: whistling, d: whistling, e: bye-bye

\section{The forehead}

Visualization of the curvature of the forehead is important to rule out a flat forehead (Figure 4). Investigators agree that microcephaly is associated with a decreased size of the frontal fossa and flattening of the frontal bone. Therefore, determination of the normal dimensions of the anterior cranial fossa and the frontal lobe of the fetal brain can provide normative
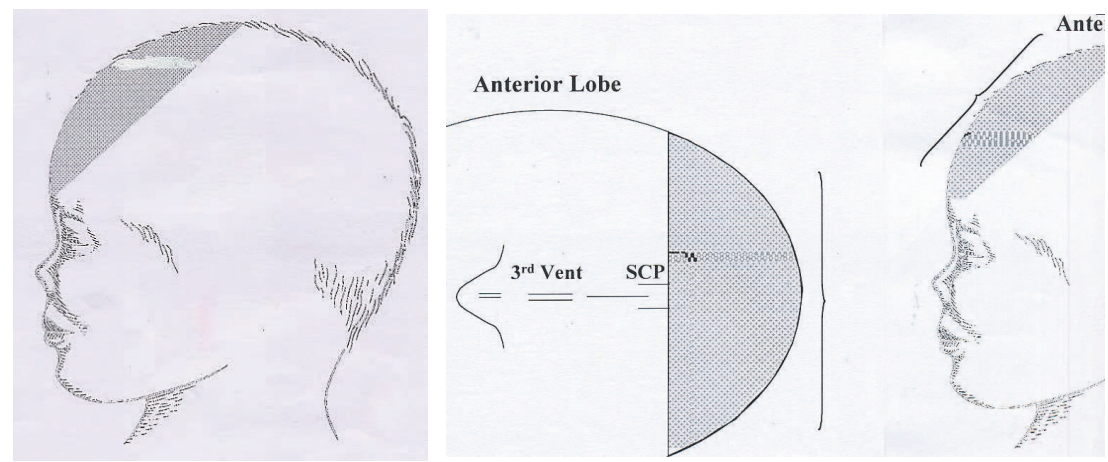

Fig. 4. Schematic picture of the anterior lobe on sagittal and axial planes 


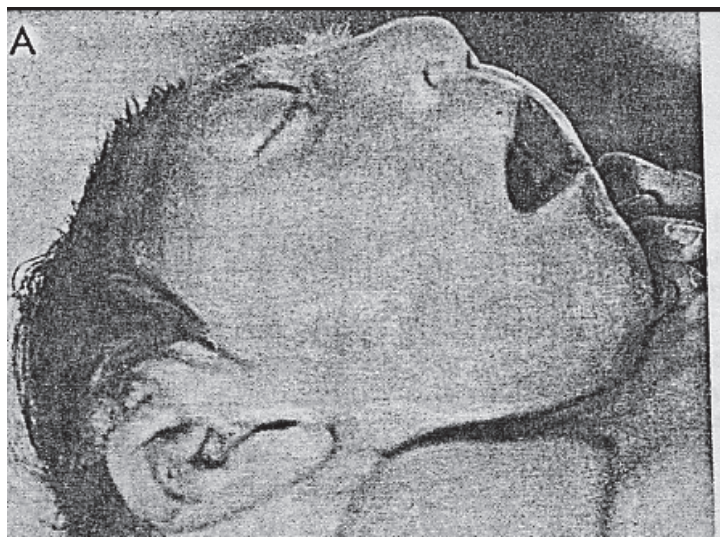

Fig. 5. A flat forehead in neonates with microcephaly

\begin{tabular}{|c|c|c|c|c|}
\hline GA [weeks] & \multicolumn{2}{|c|}{ FLD $[\mathrm{cm}]$ mean $\pm 2 S D$} & \multicolumn{2}{|c|}{ TFLD $[\mathrm{cm}]$ mean $\pm 2 S D$} \\
\hline 15 & 1.4 & 0.4 & 3.2 & 0.4 \\
\hline 16 & 1.4 & 0.4 & 3.2 & 0.4 \\
\hline 17 & 1.6 & 0.2 & 3.6 & 0.6 \\
\hline 18 & 1.6 & 0.2 & 3.7 & 0.6 \\
\hline 19 & 1.7 & 0.2 & 3.8 & 0.4 \\
\hline 20 & 1.7 & 0.2 & 4.1 & 0.4 \\
\hline 21 & 1.8 & 0.4 & 4.1 & 0.4 \\
\hline 22 & 1.8 & 0.4 & 4.6 & 0.4 \\
\hline 23 & 1.8 & 0.4 & 4.6 & 0.4 \\
\hline 24 & 1.9 & 0.2 & 4.7 & 0.4 \\
\hline 25 & 2.2 & 0.4 & 5.1 & 0.6 \\
\hline 26 & 2.3 & 0.4 & 5.2 & 0.6 \\
\hline 27 & 2.5 & 0.6 & 5.6 & 0.8 \\
\hline 28 & 2.8 & 0.2 & 5.7 & 0.4 \\
\hline 29 & 2.7 & 0.2 & 6.1 & 0.4 \\
\hline 30 & 2.8 & 0.6 & 6.2 & 1.2 \\
\hline 31 & 2.9 & 0.4 & 6.2 & 0.8 \\
\hline 32 & 3.0 & 0.6 & 6.4 & 0.8 \\
\hline 33 & 3.1 & 0.6 & 6.5 & 0.6 \\
\hline 34 & 3.2 & 0.2 & 6.7 & 0.6 \\
\hline 35 & 3.2 & 0.4 & 6.9 & 0.6 \\
\hline 36 & 3.2 & 0.4 & 7.0 & 0.4 \\
\hline 37 & 3.4 & 0.4 & 7.2 & 0.6 \\
\hline 38 & 3.5 & 0.4 & 7.3 & 0.8 \\
\hline 39 & 3.7 & 0.6 & 7.5 & 0.8 \\
\hline 40 & 4.0 & 0.6 & 7.7 & 0.8 \\
\hline
\end{tabular}

Table 2. Measurements of the mean $\pm 2 \mathrm{SD}$ of the frontal lobe distance and thalamic frontal lobe distance versus gestational age (Goldstein et al., 1988) (GA = gestational age, FLD = frontal lobe distance, TFLD = thalamic frontal lobe distance) 
data against which fetuses suspected to have microcephaly or any other lesion affecting the anterior fossa can be evaluated. A dysmorphic sign with a high frequency appears to be a flat facial profile in neonates with trisomy 21 (Smith \& Jones, 1988). Table 2 describes the normal dimensions of the frontal lobe of the fetal brain (Goldstein et al., 1988).

\section{The nasal bone}

Smallness of the nose is a common finding at postnatal examination of fetuses or neonates with trisomy 21, but also with more than 40 other genetic conditions. Measurements of the nasal bone were performed on a mid-sagittal profile in normal singleton fetuses at 14-34 weeks' gestation. It was found that the length of the nasal bones increased from $4 \mathrm{~mm}$ at 14 weeks to $12 \mathrm{~mm}$ at 35 weeks' gestation (Guis et al., 1995). Investigators examined the

\begin{tabular}{l|c|c}
\hline Gestation [weeks] & Mean & SD \\
\hline 14 & 4.183 & 0.431 \\
\hline 16 & 5.213 & 1.062 \\
\hline 18 & 6.308 & 0.654 \\
\hline 20 & 7.621 & 0.953 \\
\hline 22 & 8.239 & 1.102 \\
\hline 24 & 9.362 & 1.300 \\
\hline 26 & 9.744 & 1.277 \\
\hline 28 & 10.72 & 1.459 \\
\hline 30 & 11.348 & 1.513 \\
\hline 32 & 11.580 & 1.795 \\
\hline 34 & 12.285 & 2.372 \\
\hline
\end{tabular}

Table 3. Mean, standard deviation (SD), mean+2SD and mean-2SD for length of the nasal bones (mm) throughout gestation (Guis et al., 1995)

\begin{tabular}{l|c|c}
\hline Gestation [weeks] & Mean [mm] & SD [mm] \\
\hline $11-11.9$ & 1.7 & 0.5 \\
\hline $12-12.9$ & 2.0 & 0.5 \\
\hline $13-13.9$ & 2.3 & 0.5 \\
\hline $14-14.9$ & 3.4 & 0.7 \\
\hline $15-15.9$ & 3.3 & 0.8 \\
\hline $16-16.9$ & 4.4 & 0.7 \\
\hline $17-17.9$ & 5.0 & 0.7 \\
\hline $18-18.9$ & 5.5 & 0.9 \\
\hline $19-19.9$ & 5.7 & 0.1 \\
\hline $20-20.9$ & 6.2 & 0.1 \\
\hline
\end{tabular}

Table 4. Fetal nasal bone length (mm), 11-20 weeks' gestation (Cuick et al., 2004)

\begin{tabular}{l|c|c}
\hline Gestation [weeks] & Mean [mm] & SD [mm] \\
\hline $11-11+6$ & 1.69 & 0.26 \\
\hline $12-12+6$ & 2.11 & 0.37 \\
\hline $13-13+6$ & 2.34 & 0.39 \\
\hline $14-14+6$ & 2.94 & 0.48 \\
\hline
\end{tabular}

Table 5. Nomogram of fetal nasal bone length at 11-13 gestational weeks in fetuses (Sivri et al., 2006) 
possible improvement in screening for trisomy 21 by examining the fetal nasal bone with ultrasound at 11-14 weeks of gestation (Cicero et al., 2001). The nasal bone was absent in 43 of $59(73 \%)$ trisomy 21 fetuses, and in three of $603(0.5 \%)$ chromosomally normal fetuses.

\section{The nostrils}

Smallness of fetal nose, often attributed to hypoplasia, is a common finding during postnatal examination of fetuses or neonates with trisomy 21 (Smith \& Jones, 1988)

\begin{tabular}{l|c|c|c|c|c}
\hline \multirow{2}{*}{ GA [weeks] } & \multicolumn{5}{|c}{ Centiles } \\
\cline { 2 - 6 } & $\mathbf{1 0}$ & $\mathbf{2 5}$ & $\mathbf{5 0}$ & $\mathbf{7 5}$ & $\mathbf{9 0}$ \\
\hline $14-15$ & 5.5 & 7.2 & 7.6 & 8.3 & 10.2 \\
\hline $16-17$ & 6.5 & 7.3 & 7.9 & 8.5 & 10.5 \\
\hline $18-19$ & 8.5 & 8.9 & 10.0 & 10.5 & 11.0 \\
\hline $20-21$ & 10.2 & 11.0 & 12.0 & 12.0 & 13.0 \\
\hline 22 & 13.0 & 13.0 & 14.0 & 15.0 & 15.0 \\
\hline 23 & 13.0 & 13.0 & 14.0 & 15.0 & 15.0 \\
\hline 24 & 13.0 & 14.1 & 15.0 & 16.0 & 16.0 \\
\hline 25 & 14.2 & 15.0 & 16.3 & 17.0 & 17.0 \\
\hline 26 & 14.1 & 15.0 & 16.3 & 17.4 & 18.4 \\
\hline 27 & 13.4 & 15.4 & 17.2 & 18.4 & 19.0 \\
\hline 28 & 15.1 & 16.9 & 17.6 & 18.2 & 20.2 \\
\hline $29-30$ & 16.5 & 17.4 & 18.1 & 19.2 & 20.6 \\
\hline $31-32$ & 16.6 & 17.9 & 19.6 & 20.7 & 21.4 \\
\hline $33-34$ & 17.4 & 19.1 & 20.5 & 21.4 & 23.1 \\
\hline $35-37$ & 17.6 & 20.0 & 20.5 & 22.0 & 23.3 \\
\hline $38-40$ & 17.4 & 17.9 & 18.9 & 20.5 & 23.4 \\
\hline
\end{tabular}

Table 6. The fetal nose width (mm) (Goldstein et al., 1997)

\begin{tabular}{l|c|c|c|c|c}
\hline \multirow{2}{*}{ GA [weeks] } & \multicolumn{5}{|c}{ Centiles } \\
\cline { 2 - 6 } & $\mathbf{1 0}$ & $\mathbf{2 5}$ & $\mathbf{5 0}$ & $\mathbf{7 5}$ & $\mathbf{9 0}$ \\
\hline $14-15$ & 3.3 & 3.6 & 4.2 & 4.7 & 5.4 \\
\hline $16-17$ & 3.5 & 3.9 & 4.4 & 4.8 & 5.9 \\
\hline $18-19$ & 4.0 & 4.4 & .6 & 5.0 & 5.8 \\
\hline $20-21$ & 4.2 & 5.0 & 5.0 & 5.7 & 6.0 \\
\hline 22 & 5.0 & 5.0 & 6.0 & 6.4 & 7.0 \\
\hline 23 & 5.0 & 5.6 & 6.0 & 7.0 & 7.0 \\
\hline 24 & 5.8 & 6.0 & 6.2 & 7.3 & 7.9 \\
\hline 25 & 5.9 & 6.0 & 6.4 & 7.0 & 7.7 \\
\hline 26 & 5.1 & 6.2 & 7.7 & 8.0 & 9.0 \\
\hline 27 & 6.4 & 6.8 & 7.8 & 8.4 & 9.4 \\
\hline 28 & 6.4 & 7.0 & 7.9 & 8.6 & 9.4 \\
\hline $29-30$ & 5.4 & 7.0 & 7.0 & 8.2 & 9.6 \\
\hline $31-32$ & 4.6 & 7.4 & 7.9 & 9.2 & 10.7 \\
\hline $33-34$ & 5.4 & 6.4 & 8.1 & 9.0 & 9.7 \\
\hline $35-37$ & 5.8 & 6.6 & 8.5 & 9.6 & 10.2 \\
\hline $38-40$ & 6.0 & 6.8 & 8.5 & 9.5 & 10.5 \\
\hline
\end{tabular}

Table 7. The fetal nostril distance (mm) (Goldstein et al., 1997) 


\section{The fetal eyes}

The earliest sonographic visualization of the fetal orbit and lens has been considered to be in the beginning of the second trimester of pregnancy. On ultrasound, the orbits appear as echolucent circles in the face of the fetus, and the lens can be easily identified inside these structures. Imaging of these structures, which is possible on virtually all ultrasound examinations beyond the first trimester, is important because deviation in the relative size of the orbit and the lens can be associated with congenital malformations. The fetal orbits and lens eyes are best visualized by scanning the fetal face in coronal and axial planes. The fetal orbits should appear as two symmetrical structures on both sides of the fetal nose. Both lenses are depicted on the coronal or axial plane of the eye as circular hyperechogenic rings and with hypoechogenic areas inside the ring.

The coronal planes of the fetal face are the most important in the evaluation of the fetal orbits. Figure 6a shows the the outer orbital distance small hands, and Fig $6 \mathrm{~b}$ the inner orbital distace the small arrows. The calipers measuring the outer orbital from the lateral mid-echogenicity to the lateral mid-echogenicity, and the calipers measuring the inner orbital distace from the middle mid-echogenicity to the middle mid-echogenicity of the orbits.

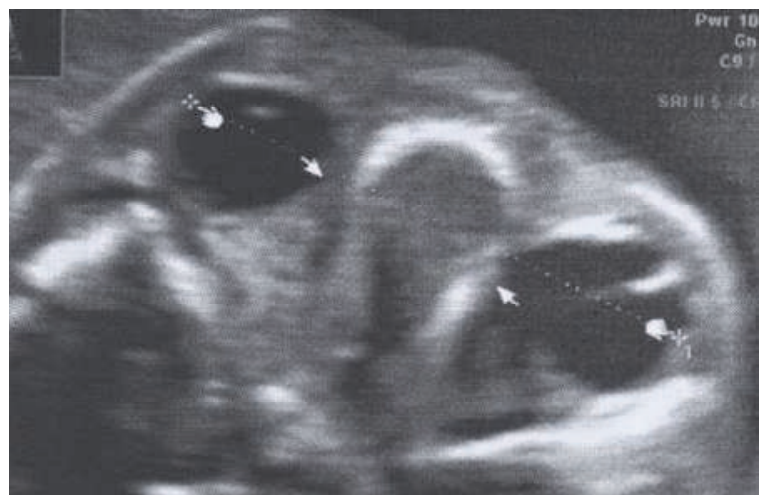

Fig. 6a. Coronal plane of the fetal orbits - small hands showing the outer orbital diameter measurement

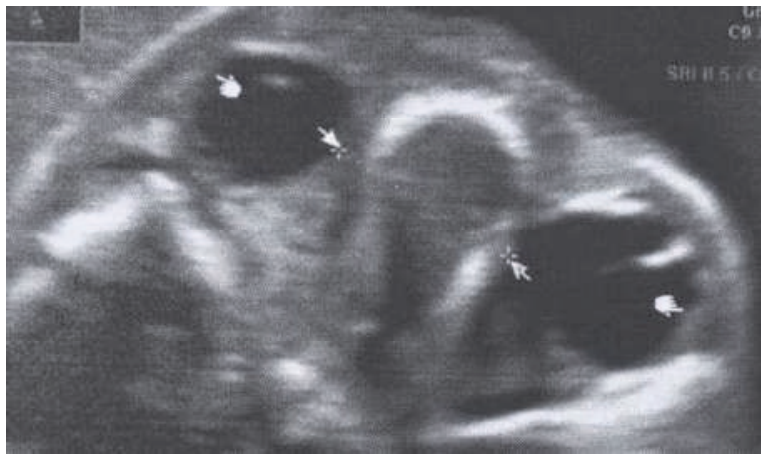

Fig. 6b. Coronal plane of the fetal orbits - small arrows showing the inner orbital diameter measurement 


\begin{tabular}{l|c|c|c|c|c|c|c|c}
\hline GA & $\mathbf{N}$ & Mean & $\mathbf{9 5 \%} \mathbf{C I}$ & \multicolumn{3}{|c}{ Centiles } \\
\cline { 5 - 8 } [weeks] & & & & $\mathbf{1 0}$ & $\mathbf{2 5}$ & $\mathbf{5 0}$ & $\mathbf{7 5}$ & $\mathbf{9 0}$ \\
\hline 14 & 10 & 5.2 & $4.8-5.7$ & 4.5 & 5.0 & 5.3 & 5.7 & 90 \\
\hline 15 & 26 & 6.1 & $5.9-6.3$ & 5.4 & 5.5 & 6.2 & 6.5 & 6.7 \\
\hline 16 & 25 & 6.6 & $6.3-6.9$ & 5.8 & 6.2 & 6.5 & 7.0 & 7.6 \\
\hline $17-18$ & 19 & 7.3 & $6.7-7.8$ & 6.2 & 6.5 & 6.7 & 9.0 & 9.0 \\
\hline $19-20$ & 23 & 9.8 & $9.3-10.2$ & 8.6 & 9.0 & 10.0 & 10.1 & 11.3 \\
\hline 21 & 19 & 10.5 & $10.0-10.9$ & 9.4 & 9.9 & 10.0 & 11.0 & 12.0 \\
\hline 22 & 26 & 10.4 & $10.0-10.7$ & 9.5 & 9.6 & 10.5 & 11.0 & 11.3 \\
\hline 23 & 21 & 10.7 & $10.4-11.1$ & 9.6 & 10.0 & 10.5 & 11.4 & 11.5 \\
\hline 24 & 19 & 11.6 & $11.3-11.8$ & 10.7 & 11.0 & 11.5 & 12.0 & 12.5. \\
\hline 25 & 13 & 11.2 & $11.4-12.4$ & 10.3 & 11.0 & 12.2 & 12.5 & 12.8 \\
\hline 26 & 16 & 12.7 & $12.0-13.4$ & 11.0 & 11.0 & 12.7 & 13.8 & 14.5 \\
\hline 27 & 14 & 13.0 & $12.4-13.5$ & 11.9 & 12.0 & 12.9 & 13.4 & 14.8 \\
\hline 28 & 21 & 13.0 & $12.7-13.3$ & 21.1 & 12.0 & 13.1 & 13.3 & 14.1 \\
\hline 29 & 23 & 13.9 & $13.4-14.4$ & 12.6 & 13.0 & 13.7 & 14.6 & 15.7 \\
\hline $30-31$ & 24 & 14.2 & $13.8-14.5$ & 13.3 & 13.0 & 13.9 & 14.7 & 15.4 \\
\hline $32-33$ & 24 & 14.4 & $13.7-15.1$ & 12.2 & 13.0 & 14.1 & 14.8 & 17.5 \\
\hline $34-36$ & 26 & 15.8 & $15.4-16.2$ & 14.6 & 15.0 & 15.7 & 16.5 & 16.9 \\
\hline
\end{tabular}

Table 8. The fetal orbital diameter (mm) (Goldstein et al., 1998) GA = gestational age; $\mathrm{CI}=$ confidence interval

\begin{tabular}{l|c|c|c|c|c|c|c|c}
\hline GA & \multirow{2}{*}{ [weeks] } & Mean & $\mathbf{9 5 \%}$ CI & \multicolumn{6}{|c}{ Centiles } \\
\cline { 5 - 8 } & & & & $\mathbf{1 0}$ & $\mathbf{2 5}$ & $\mathbf{5 0}$ & $\mathbf{7 5}$ & $\mathbf{9 0}$ \\
\hline 14 & 10 & 2.5 & $23.3-2.7$ & 2.1 & 2.4 & 2.5 & 2.7 & 2.9 \\
\hline 15 & 26 & 2.9 & $2.9-3.0$ & 2.7 & 2.8 & 2.9 & 3.1 & 3.2 \\
\hline 16 & 25 & 2.9 & $2.8-3.0$ & 2.7 & 2.8 & 2.9 & 3.1 & 3.2 \\
\hline $17-18$ & 19 & 3.3 & $3.0-3.6$ & 2.8 & 2.9 & 3.0 & 3.3 & 5.0 \\
\hline $19-20$ & 23 & 4.1 & $4.0-4.3$ & 3.6 & 4.0 & 4.0 & 4.3 & 5.0 \\
\hline 21 & 19 & 4.4 & $4.1-4.6$ & 3.7 & 3.9 & 4.0 & 5.0 & 5.0 \\
\hline 22 & 26 & 4.4 & $4.2-4.7$ & 3.9 & 4.0 & 4.3 & 5.0 & 5.0 \\
\hline 23 & 21 & 4.6 & $4.3-4.8$ & 3.8 & 4.0 & 5.0 & 5.0 & 5.0 \\
\hline 24 & 19 & 4.6 & $4.4-4.8$ & 4.0 & 4.3 & 4.6 & 5.0 & 5.0 \\
\hline 25 & 13 & 4.8 & $4.6-5.0$ & 4.2 & 4.6 & 5.0 & 5.1 & 5.2 \\
\hline 26 & 16 & 5.0 & $4.8-5.2$ & 4.4 & 4.8 & 5.1 & 5.2 & 5.5 \\
\hline 27 & 14 & 5.0 & $5.0-5.2$ & 4.5 & 5.0 & 5.2 & 5.2 & 5.5 \\
\hline 28 & 21 & 5.1 & $5.0-5.2$ & 4.5 & 5.0 & 5.2 & 5.2 & 5.5 \\
\hline 29 & 23 & 5.3 & $5.1-5.5$ & 4.6 & 5.2 & 5.2 & 5.5 & 5.9 \\
\hline $30-31$ & 24 & 5.3 & $5.2-5.5$ & 4.8 & 5.1 & 5.5 & 5.5 & 5.7 \\
\hline $32-33$ & 24 & 5.6 & $5.4-5.8$ & 4.8 & 5.2 & 5.5 & 5.9 & 6.2 \\
\hline $34-36$ & 26 & 5.8 & $5.6-6.0$ & 5.4 & 5.5 & 5.7 & 6.0 & 6.5 \\
\hline
\end{tabular}

Table 9. Diameter of orbital lens (mm) (Goldstein et al., 1998) GA = gestational age; $\mathrm{CI}=$ confidence interval) 


\subsection{Hypotelorism}

Hypotelorism is a condition pertaining to abnormally close eyes.

\begin{tabular}{|c|c|c|c|c|c|c|}
\hline \multirow{2}{*}{ GA [weeks] } & \multicolumn{3}{|c|}{ OOD [mm] } & \multicolumn{3}{|c|}{ IOD [mm] } \\
\hline & $5^{\text {th }}$ & $50^{\text {th }}$ & $9^{\text {th }}$ & $5^{\text {th }}$ & $50^{\text {th }}$ & $95^{\text {th }}$ \\
\hline 12 & 8 & 15 & 23 & 4 & 9 & 13 \\
\hline 13 & 10 & 18 & 25 & 5 & 9 & 14 \\
\hline 14 & 13 & 20 & 28 & 5 & 10 & 14 \\
\hline 15 & 15 & 22 & 30 & 6 & 10 & 14 \\
\hline 16 & 17 & 25 & 32 & 6 & 10 & 15 \\
\hline 17 & 19 & 27 & 34 & 6 & 11 & 15 \\
\hline 18 & 22 & 29 & 37 & 7 & 11 & 16 \\
\hline 19 & 24 & 31 & 39 & 7 & 12 & 16 \\
\hline 20 & 26 & 33 & 41 & 8 & 12 & 17 \\
\hline 21 & 28 & 35 & 43 & 8 & 13 & 17 \\
\hline 22 & 30 & 37 & 44 & 9 & 13 & 18 \\
\hline 23 & 31 & 39 & 46 & 9 & 14 & 18 \\
\hline 24 & 33 & 41 & 48 & 10 & 14 & 19 \\
\hline 25 & 35 & 42 & 50 & 10 & 15 & 19 \\
\hline 26 & 36 & 44 & 51 & 11 & 15 & 20 \\
\hline 27 & 38 & 45 & 53 & 11 & 16 & 20 \\
\hline 28 & 39 & 47 & 54 & 12 & 16 & 21 \\
\hline 29 & 41 & 48 & 56 & 12 & 17 & 21 \\
\hline 30 & 42 & 50 & 57 & 13 & 17 & 22 \\
\hline 31 & 43 & 51 & 56 & 13 & 18 & 22 \\
\hline 32 & 45 & 52 & 60 & 14 & 18 & 23 \\
\hline 33 & 46 & 53 & 61 & 14 & 19 & 23 \\
\hline 34 & 47 & 54 & 62 & 15 & 19 & 24 \\
\hline 35 & 48 & 55 & 63 & 15 & 20 & 24 \\
\hline 36 & 49 & 56 & 64 & 16 & 20 & 25 \\
\hline 37 & 50 & 57 & 65 & 16 & 21 & 25 \\
\hline 38 & 50 & 58 & 65 & 17 & 21 & 21 \\
\hline 39 & 51 & 58 & 66 & 17 & 22 & 26 \\
\hline 40 & 52 & 59 & 67 & 18 & 22 & 26 \\
\hline
\end{tabular}

Table 10. The outer orbital diameter (OOD) and inner orbital diameter (IOD), GA = gestational age (Jeanty et al., 1984) 


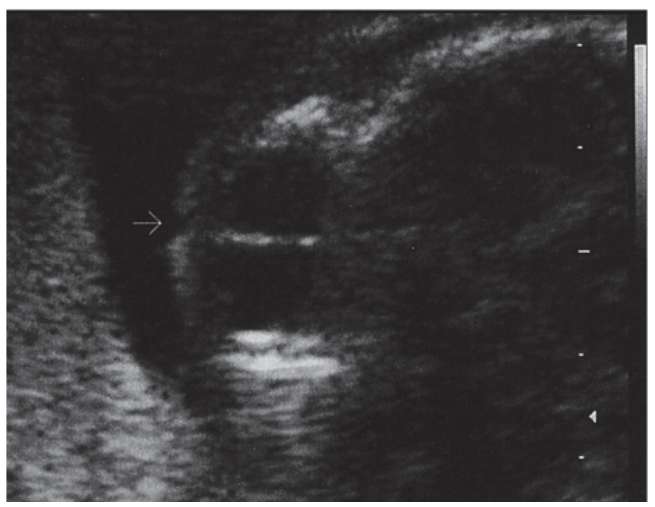

Fig. 7. Axial scan of a fetus at 25.3 weeks of gestation showing severe hypotelorism

\begin{tabular}{|c|c|c|c|}
\hline BPD [cm] & Weeks' gestation & IOD [cm] & OOD [cm] \\
\hline 1.9 & 11.6 & 0.5 & 1.3 \\
\hline 2.0 & 11.6 & 0.5 & 1.4 \\
\hline 2.1 & 12.1 & 0.6 & 1.5 \\
\hline 2.2 & 12.6 & 0.6 & 1.6 \\
\hline 2.3 & 12.6 & 0.6 & 1.7 \\
\hline 2.4 & 13.1 & 0.7 & 1.7 \\
\hline 2.5 & 13.6 & 0.7 & 1.8 \\
\hline 2.6 & 13.6 & 0.7 & 1.9 \\
\hline 2.7 & 14.1 & 0.8 & 2.0 \\
\hline 2.8 & 14.6 & 0.8 & 2.1 \\
\hline 2.9 & 14.6 & 0.8 & 2.1 \\
\hline 3.0 & 15.0 & 0.9 & 2.2 \\
\hline 3.1 & 15.5 & 0.9 & 2.3 \\
\hline 3.2 & 15.5 & 0.9 & 2.4 \\
\hline 3.3 & 16.0 & 1.0 & 2.5 \\
\hline 3.4 & 16.5 & 1.0 & 2.5 \\
\hline 3.5 & 16.5 & 1.0 & 2.6 \\
\hline 3.6 & 17.0 & 1.0 & 2.7 \\
\hline 3.7 & 17.5 & 1.1 & 2.7 \\
\hline 3.8 & 17.9 & 1.1 & 2.8 \\
\hline 4.0 & 18.4 & 1.2 & 3.0 \\
\hline 4.2 & 18.9 & 1.2 & 3.1 \\
\hline 4.3 & 19.4 & 1.2 & 3.2 \\
\hline 4.4 & 19.4 & 1.3 & 3.2 \\
\hline 4.5 & 19.9 & 1.3 & 3.3 \\
\hline 4.6 & 20.4 & 1.3 & 3.4 \\
\hline 4.7 & 20.4 & 1.3 & 3.4 \\
\hline 4.8 & 20.9 & 1.4 & 3.5 \\
\hline 4.9 & 21.3 & 1.4 & 3.6 \\
\hline 5.0 & 21.3 & 1.4 & 3.6 \\
\hline
\end{tabular}




\begin{tabular}{|c|c|c|c|}
\hline BPD [cm] & Weeks' gestation & IOD [cm] & OOD [cm] \\
\hline 5.1 & 21.8 & 1.4 & 3.7 \\
\hline 5.2 & 22.3 & 1.4 & 3.8 \\
\hline 5.3 & 22.3 & 1.5 & 3.8 \\
\hline 5.4 & 22.8 & 1.5 & 3.9 \\
\hline 5.5 & 23.9 & 1.5 & 4.0 \\
\hline 5.6 & 23.3 & 1.5 & 4.0 \\
\hline 5.7 & 23.8 & 1.5 & 4.1 \\
\hline 5.8 & 24.3 & 1.6 & 4.1 \\
\hline 5.9 & 24.3 & 1.6 & 4.2 \\
\hline 6.0 & 24.7 & 1.6 & 4.3 \\
\hline 6.1 & 25.2 & 1.6 & 4.3 \\
\hline 6.2 & 25.2 & 1.6 & 4.4 \\
\hline 6.3 & 25.7 & 1.7 & 4.4 \\
\hline 6.4 & 26.2 & 1.7 & 4.5 \\
\hline 6.5 & 26.2 & 1.7 & 4.5 \\
\hline 6.6 & 26.7 & 1.7 & 4.6 \\
\hline 6.7 & 27.2 & 1.7 & 4.6 \\
\hline 6.8 & 27.6 & 1.7 & 4.7 \\
\hline 6.9 & 28.1 & 1.7 & 4.7 \\
\hline 7.0 & 28.6 & 1.8 & 4.8 \\
\hline 7.1 & 29.1 & 1.8 & 4.8 \\
\hline 7.3 & 29.6 & 1.8 & 4.9 \\
\hline 7.4 & 30.0 & 1.8 & 5.0 \\
\hline 7.5 & 30.6 & $1 . .8$ & 5.0 \\
\hline 7.6 & 31.0 & 1.8 & 5.1 \\
\hline 7.7 & 31.5 & 1.8 & 5.1 \\
\hline 7.8 & 32.0 & 1.8 & 5.2 \\
\hline 7.9 & 32.5 & 1.9 & 5.2 \\
\hline 8.0 & 33.0 & 1.9 & 5.3 \\
\hline 8.2 & 33.5 & 1.9 & 5.4 \\
\hline 8.3 & 34.0 & 1.9 & 5.4 \\
\hline 8.4 & 34.4 & 1.9 & 5.4 \\
\hline 8.5 & 35.0 & 1.9 & 5.5 \\
\hline 8.6 & 35.4 & 1.9 & 5.5 \\
\hline 8.8 & 35.9 & 1.9 & 5.6 \\
\hline 8.9 & 36.4 & 1.9 & 5.6 \\
\hline 9.0 & 36.9 & 1.9 & 5.7 \\
\hline 9.1 & 37.3 & 1.9 & 5.7 \\
\hline 9.2 & 37.8 & 1.9 & 5.8 \\
\hline 9.3 & 38.3 & 1.9 & 5.8 \\
\hline 9.4 & 38.8 & 1.9 & 5.8 \\
\hline 9.6 & 39.3 & 1.9 & 5.8 \\
\hline 9.7 & 39.8 & 1.9 & 5.9 \\
\hline
\end{tabular}

Table 11. Predicted BPD and weeks' gestation from the inner orbital diameter (IOD) and outer orbital diameter (OOD) (Mayden et al., 1982) 


\subsection{Hypertelorism}

Hypertelorism is an abnormally increased distance between two organs or body parts, usually referring to an increased distance between the eyes (orbital hypertelorism), seen in a variety of syndromes (Table 12).

\begin{tabular}{|c|c|}
\hline Malformation & Syndromes \\
\hline Anophthalmus & $\begin{array}{l}\text { Trisomy } 13 \\
\text { Vilaret, Weyers-Tier, ocular vertebral syndrome }\end{array}$ \\
\hline Microphthalmus & $\begin{array}{l}\text { Autosomal recessive or autosomal dominant } \\
\text { Intrauterine infection } \\
\text { Radiation } \\
\text { Chromosomal aberration } \\
\text { X-linked } \\
\text { Associated with gingival fibromatosis } \\
\text { Depigmentation }\end{array}$ \\
\hline Ocular hypotelorism & $\begin{array}{l}\text { Chromosome } 5 \text { p-syndrome } \\
\text { Chromosome } 15 \text {-p-proximal partial trisomy syndrome } \\
\text { Chromosome } 13 \text { trisomy } \\
\text { Craniosynostosis-medical aplasia syndrome } \\
\text { Holoprosencephaly } \\
\text { Meckel syndrome }\end{array}$ \\
\hline Ocular hypetelorism & $\begin{array}{l}\text { Aarshog syndrome } \\
\text { Acrocephalosyndactyly } \\
\text { Acrodystasis } \\
\text { Auditory canal atresia } \\
\text { Basal nevus syndrome } \\
\text { Branchio-skeleto-genital syndrome } \\
\text { Broad thumb-hallux syndrome } \\
\text { Campomelic dysplasia } \\
\text { Cerebro-hepato-renal syndrome } \\
\text { Chromosome } 18 \text { p- syndrome } \\
\text { Chromosome } 5 \text { p- syndrome } \\
\text { Chromosome } 4 \text { p- syndrome } \\
\text { Chromosome } 14 \text { p-proximal partial trisomy syndrome } \\
\text { Coffin-Lowry syndrome } \\
\text { Cranio-carpo tarsal dysplasia } \\
\text { Cranio-facial dysostosis }\end{array}$ \\
\hline
\end{tabular}




\begin{tabular}{|c|c|}
\hline Malformation & Syndromes \\
\hline & 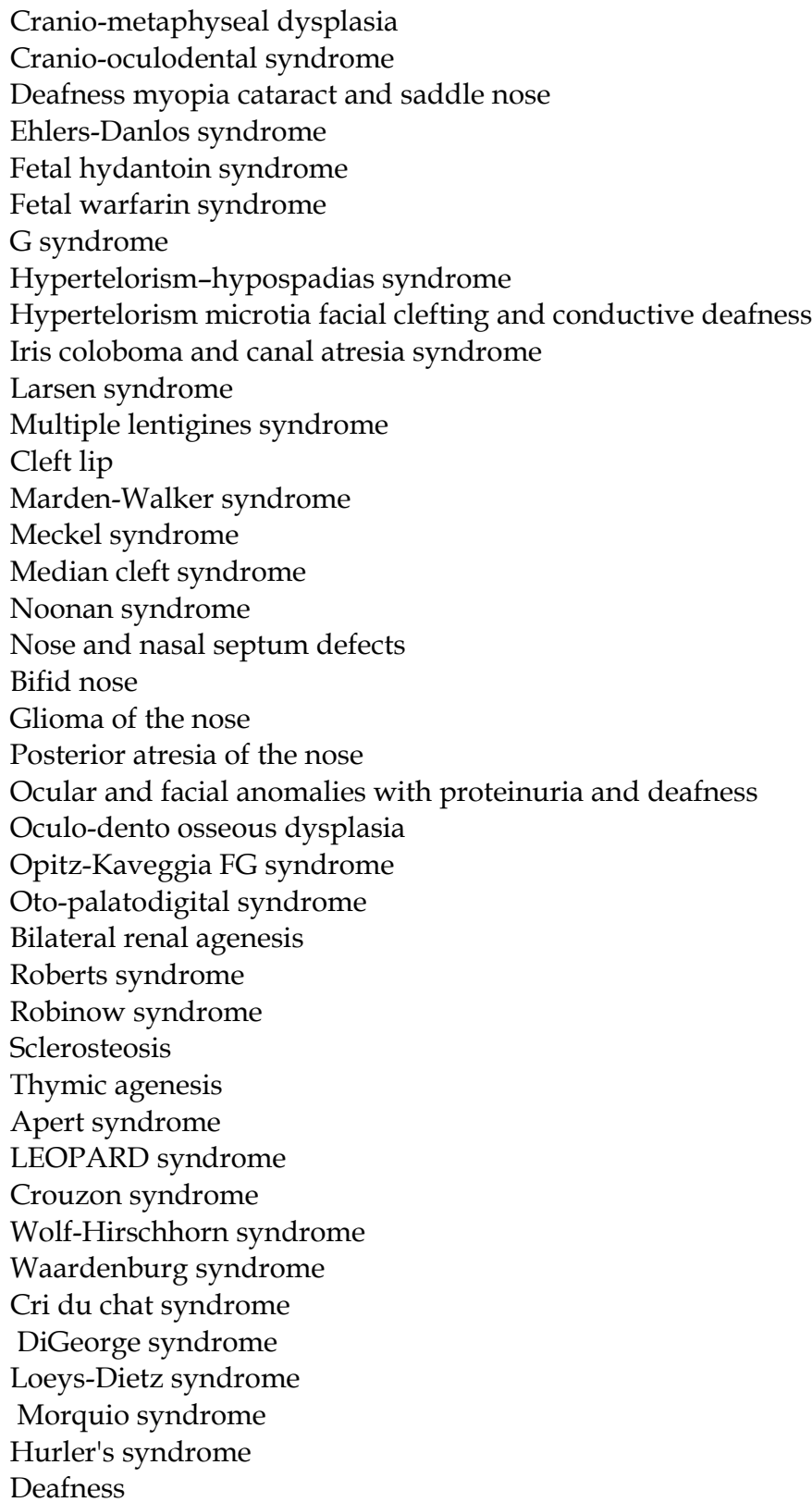 \\
\hline
\end{tabular}

Table 12. Syndromes associated with fetal ocular malformation (Bergsma, 1979) 


\subsection{Cyclopia}

Cyclopia is an anomaly characterized by a single orbital fossa, with fusion of bulbs, eyelids and lacrimal apparatus to a variable degree. Usually there is a single eye or partially divided eye in a single orbit and arhinia with proboscis. A normal nose is absent and a proboscis structure originating from the nasal root may be seen (Bergsma, 1979). The differential diagnosis in these cases includes ethmocephaly (extreme hypotelorism, arhinia and blinded proboscis located between the eyes) and ceboephaly (hypotelorism and a single nostril nose, without midline cleft). In ethmocephaly, the nasal bones, maxilla and nasal septum and turbinate are missing and lacrimal and palatine bones are united (Goldstein et al., 2003; McGahan et al., 1990).
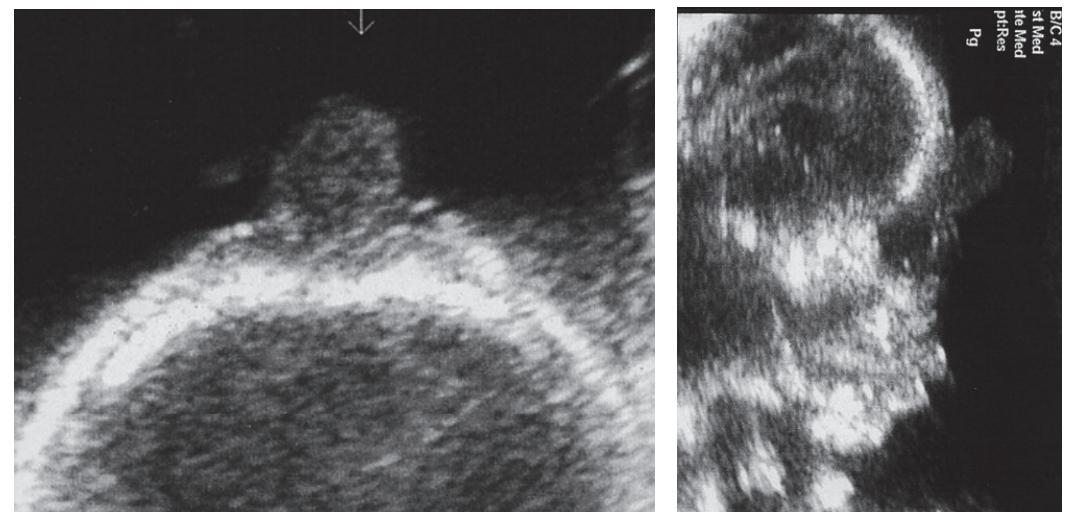

Fig. 8. Axial and sagittal scans of a fetus at 25.3 weeks of gestation show prominent forehead and proboscis

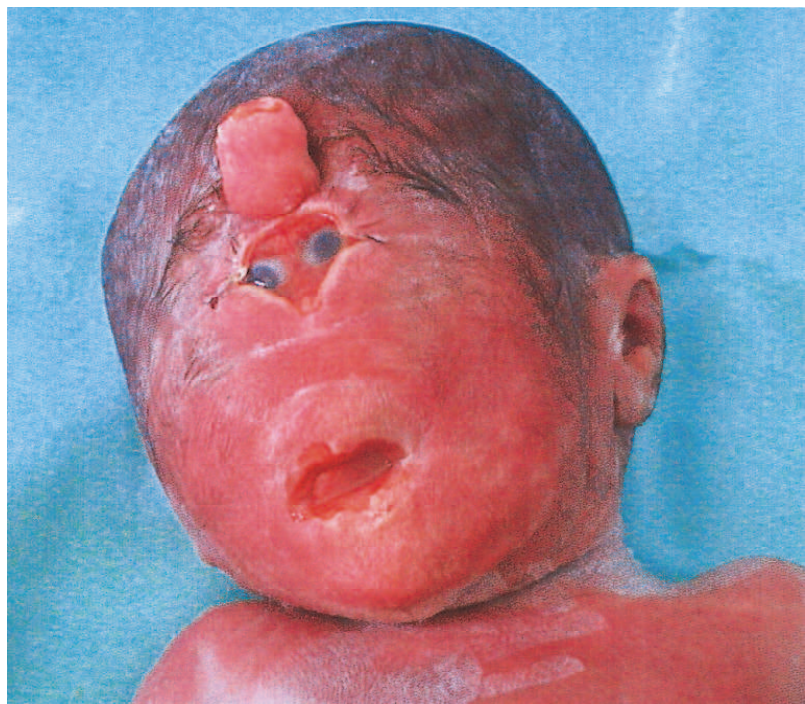

Fig. 9. Ethmocephaly - postmortem demonstrating hypotelorism and proboscis 


\subsection{Cataracts}

A cataract is an opacity of the lens and accounts for $10 \%$ of the blindness seen in preschool age children in Western countries. Fetal cataracts may occur in association with infectious diseases, chromosomal anomalies or systemic syndromes.
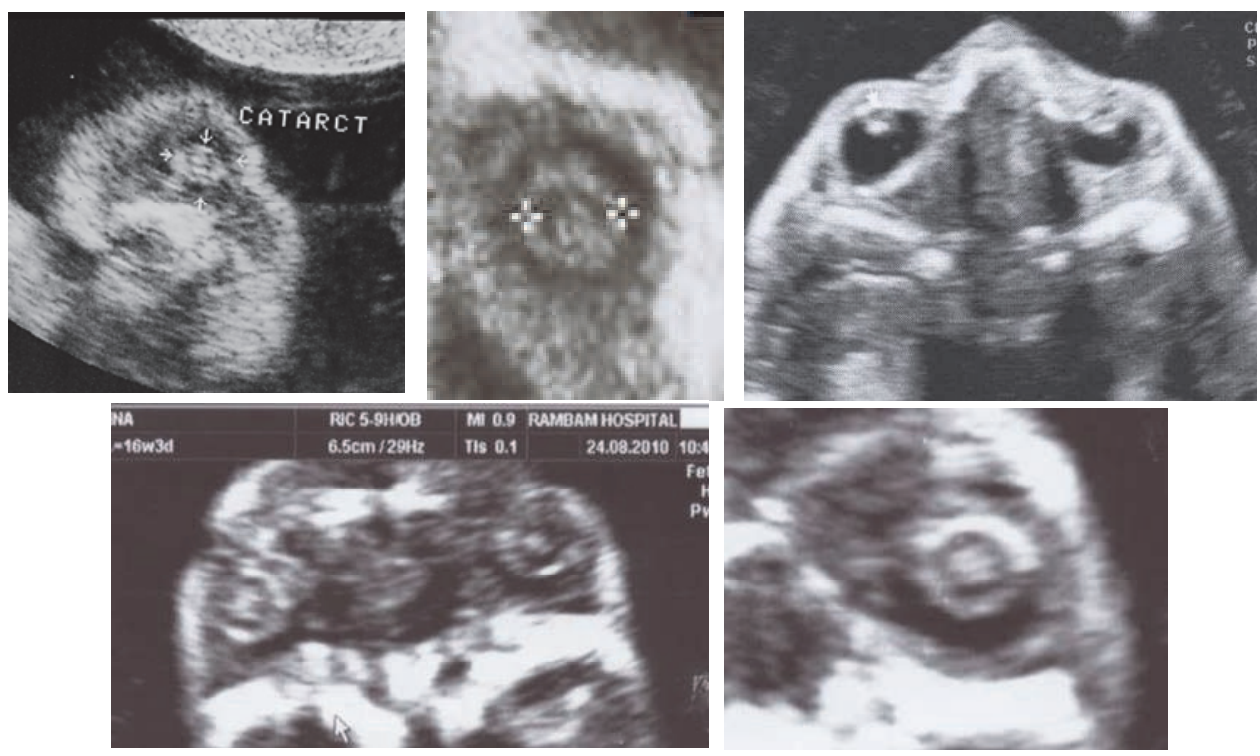

Fig. 10. Sonographic pictures of fetal cataracts at 15 weeks of gestation. Coronal views of echogenic lens.

\section{The ear}

Abnormally small ears have been noted to be one of the findings in newborn and infants with trisomy 21 and other aneuploidies. Ears in these infants are often described as small, low-set, and malformed. Short ear length has been found to be the most consistent clinical characteristic in making the diagnosis of Downs' syndrome (Aase et al., 1973). Sonographically, a short fetal ear length may be a parameter in predicting fetal aneouploidy (Chitkara et al., 2002). Sonographic studies have suggested that short ear length measurements might be a useful predictor of fetal anomalies (Awwad et al., 1994; Lettieri et al., 1993; Shimizu et al., 1997; Yeo et al., 1998).

Investigators had suggested that the fetal ear length may be a useful measurement in prediction of aneuploidy in patients at high risk for fetal chromosomal abnormalities (Awwad et al., 1994; Lettieri et al., 1993; Shimizu et al., 1997; Yeo et al., 1998). However, it remains to be determined whether this measurement alone, or in combination with other aneuploidy markers, will prove to be a useful predictor of aneuploidy in a population of women at low risk for fetal chromosomal abnormalty. 


\begin{tabular}{|c|c|c|}
\hline GA (Weeks) & Mean [mm] & $\mathrm{SD}$ [mm] \\
\hline 14 & 8 & 0.7 \\
\hline 15 & 9 & 1.8 \\
\hline 16 & 10 & 0.9 \\
\hline 17 & 11 & 1.0 \\
\hline 18 & 13 & 0.7 \\
\hline 19 & 14 & 1.1 \\
\hline 20 & 15 & 1.1 \\
\hline 21 & 17 & 1.0 \\
\hline 22 & 18 & 1.5 \\
\hline 23 & 19 & 1.4 \\
\hline 24 & 20 & 1.1 \\
\hline 25 & 22 & 1.7 \\
\hline 26 & 23 & 2.1 \\
\hline 27 & 25 & 1.7 \\
\hline 28 & 26 & 1.8 \\
\hline 29 & 26 & 1.6 \\
\hline 30 & 27 & 2.3 \\
\hline 31 & 29 & 2.6 \\
\hline 32 & 29 & 1.9 \\
\hline 33 & 30 & 1.8 \\
\hline 34 & 31 & 1.6 \\
\hline 35 & 31 & 2.1 \\
\hline 36 & 33 & 2.6 \\
\hline 37 & 33 & 2.0 \\
\hline 38 & 33 & 4.1 \\
\hline 39 & 34 & 4.3 \\
\hline 40 & 37 & 2.1 \\
\hline 41 & 38 & 1.9 \\
\hline
\end{tabular}

Table 13. Fetal ear length (Yeo et al., 1998)

\section{The maxillary bone}

Imaging of the maxillary bone is possible in most ultrasound examinations and is important, because deviations in maxillary bone development can also be associated with a malformed face. The relationship between the maxillary, zygomatic and palatine bones provides a capacity for rapid movement of the fetal face. The etiology of hypoplasia of the maxillary bone may, in some cases, form part of well-established structural abnormalities in the fetus 
such as choanal atresia, or genetic syndromes such as Marfan's syndrome. Sonographically, early prenatal detection of the maxillary bone is possible at 14 week of gestation. Hypoplasia of the maxillary bone can appear as an incidental finding. Table 14 depicts nomograms of the maxillary bone length.

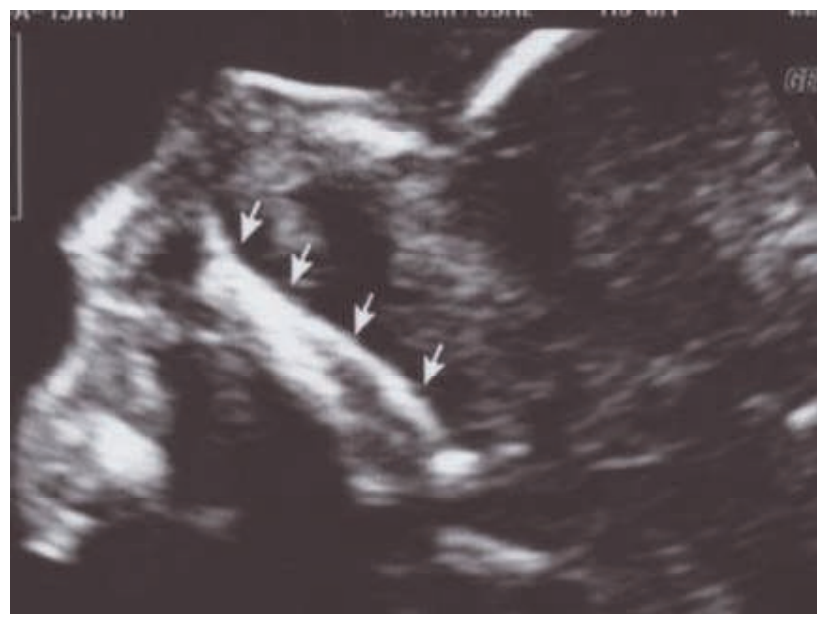

Fig. 11. Sonographic picture of the maxillary bone

\begin{tabular}{llllll} 
GA & Mean & SD & \multicolumn{3}{c}{ Centiles.......... } \\
\multicolumn{1}{l}{ (Weeks) } & & & $\mathbf{1 0}$ & $\mathbf{5 0}$ & $\mathbf{9 0}$ \\
14 & 9.97 & 1.12 & 8.32 & 10 & 11.52 \\
15 & 10.64 & 1.07 & 9.4 & 10.6 & 11.8 \\
16 & 10.6 & 1.73 & 7.6 & 10.4 & 12.98 \\
$17-19$ & 10.07 & 2.75 & 7.0 & 10.9 & 13 \\
$20-22$ & 11.48 & 3.42 & 7.0 & 11.0 & 17.35 \\
$23-24$ & 13.19 & 3.34 & 8.60 & 13 & 16.76 \\
$25-26$ & 12.85 & 1.74 & 10.2 & 13.0 & 15.92 \\
$27-28$ & 12.61 & 2.11 & 10.0 & 12.0 & 16.2 \\
$29-30$ & 13.63 & 1.67 & 11.67 & 13.50 & 16.23 \\
31 & 13.16 & 1.25 & 11 & 13.0 & 15.48 \\
32 & 13.49 & 1.25 & 11.9 & 13.45 & 15.0 \\
33 & 13.7 & 1.37 & 11.11 & 14.0 & 15.95 \\
34 & 13.87 & 1.72 & 11.96 & 14.0 & 16.15 \\
35 & 14.15 & 1.27 & 12.54 & 14.0 & 16.0 \\
36 & 14.31 & 1.4 & 12.63 & 14.35 & 16.15 \\
37 & 14.08 & 1.26 & 12.93 & 14.0 & 16.73 \\
$38-39$ & 14.84 & 1.77 & 11.74 & 14.8 & 17.47
\end{tabular}

Table 14. Maxillary bone length across gestational age (Goldstein et al., 2005)

The frontomaxillary facial (FMF) angle was studied in the first trimester in a Chinese population, demonstrating that the FMF angle decreases with fetal CRL increases. Similarity in the normal values of the FMF angle was found between the Chinese and Caucasian 
populations (Chen et al., 2011). These authors previously studied the FMF angle in fetuses with trisomy 21 in the first trimester and found significant differences in the FMF angle between normal fetuses and fetuses with trisomy 21 in the Chinese population (Chen et al., 2009).

\section{The tongue}

Fetal macroglossia and microglossia are associated with several chromosomal defects. Table 15 describes the tongue circumference between 14 and 26 weeks of gestation.

$\begin{array}{llll}\frac{\text { GA }}{(\text { weeks) }} & \text { Lower 95\% CI } & \text { Mean } & \text { Upper 95\% CI } \\ \frac{14}{14} & 24 & & \\ 15 & 26 & 28 & 31 \\ 16 & 33 & 33 & 36 \\ 17 & 37 & 36 & 38 \\ 18 & 40 & 37 & 38 \\ 19 & 47 & 43 & 46 \\ 20 & 47 & 48 & 51 \\ 21 & 51 & 51 & 56 \\ 22 & 52 & 55 & 61 \\ 23 & 58 & 58 & 62 \\ 24 & 60 & 62 & 68 \\ 25 & 68 & 64 & 67 \\ 26 & 71 & 70 & 73 \\ & & 73 & 76\end{array}$

Table 15. Tongue circumference $(\mathrm{mm})$ by gestational age (weeks) and the $95 \%$ confidence interval (Achiron et al., 1997)

\section{Cleft lips \& palate}

Cleft lip and palate is a common facial anomaly, with an incidence of 1 in 1000 live births. The incidence in fetuses is much higher, and many of these also have other malformations. Cleft palate alone occurs in about 1 of 2,500 white births. Cleft lip is more common in males, and cleft palate is more common in females. Cleft lip is one or more splits (clefts) in the upper lip. Cleft lip can range from a small indentation in the lip to a split in the lip that may extend up into one or both nostrils. Cleft lip develops in about the sixth to eighth week of gestation, when structures in the upper jaw do not fuse properly and the upper lip does not completely merge. Sometimes the nasal cavity, palate, and upper teeth are also affected in an opening in the roof of the mouth that develops when the cleft palate bones and tissues do not completely join during fetal growth, sometime between the $7^{\text {th }}$ and $12^{\text {th }}$ weeks of gestation. The severity and type of cleft palate vary according to where the cleft occurs on the palate and whether all the layers of the palate are affected. A mild form of cleft palate may not be visible because tissue covers the cleft. A complete cleft palate involves all layers of tissue of the soft palate, extends to and includes the hard palate, and may continue to the lip and nose. Sometimes problems associated with cleft palate also include deformities of the nasal cavities and/or the partition separating them (septum). 
An ultrasound detection of cleft lip and palate may be seen as early as 14 to 16 weeks of gestation. Cleft palate and cleft lip may occur independent of each other or at the same time. The hard palate is the front part of the roof of the mouth, and the soft palate is the back part of the roof of the mouth. This description may include whether the uvulais affected. The latter is impossible to detect prenatally. Cleft lip is classified according to its location and severity. Unilateral cleft lip affects one side of the mouth; bilateral cleft lip affects both sides of the mouth. A complete cleft lip is a deep split in the upper lip extending into one or both sides of the nose; an incomplete cleft lip affects only one side of the upper lip. It may appear as a slight indentation or as a deep notch.
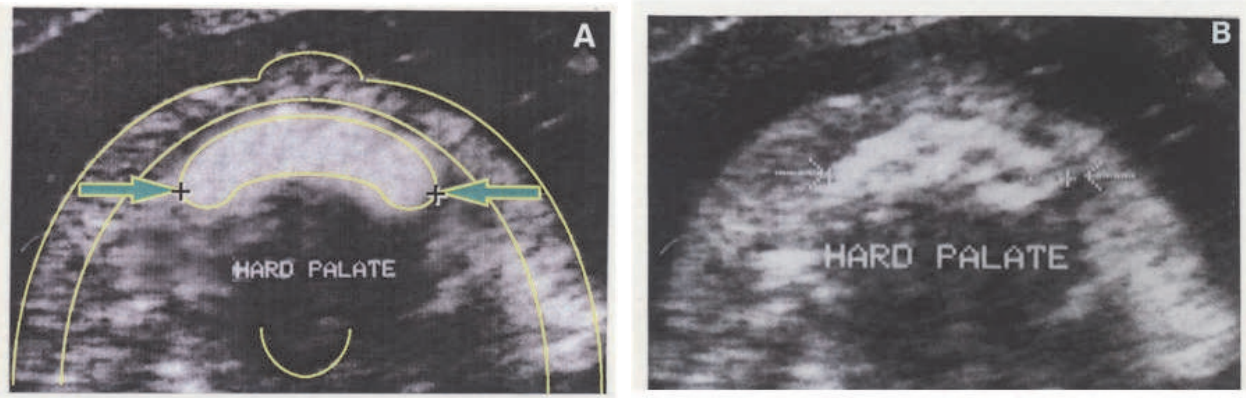

Fig. 12. Sonographic picture of normal primary palate (The alveolar ridge)
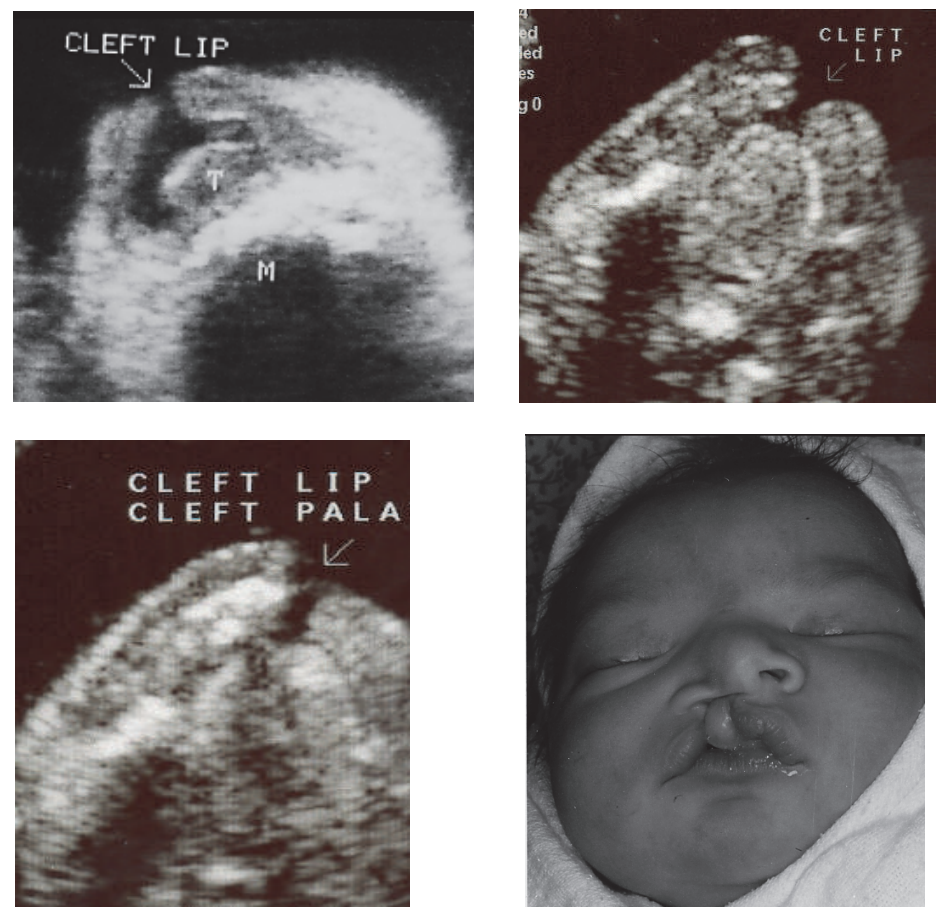

Fig. 13. Sonographic pictures of cleft lip 
Ultrasonography can be used to identify clefting in the lip and primary palate (alveolar ridge). The ultrasound detecting rates of facial clefting have been reported as low as $21-30 \%$ using two-dimensional ultrasound (Crane et al., 1994). Accurate characterization of the fetal clefting is an important aspect of ultrasound diagnosis. Three-dimensional ultrasound may be useful in defining the location and extent of facial clefting in utero (Johnson et al., 2000). Although three-dimensional images of the fetal alveolar ridge can be obtained, twodimensional sonographic images are obtained more easily, rapidly and accurately (Goldstein et al., 1999).
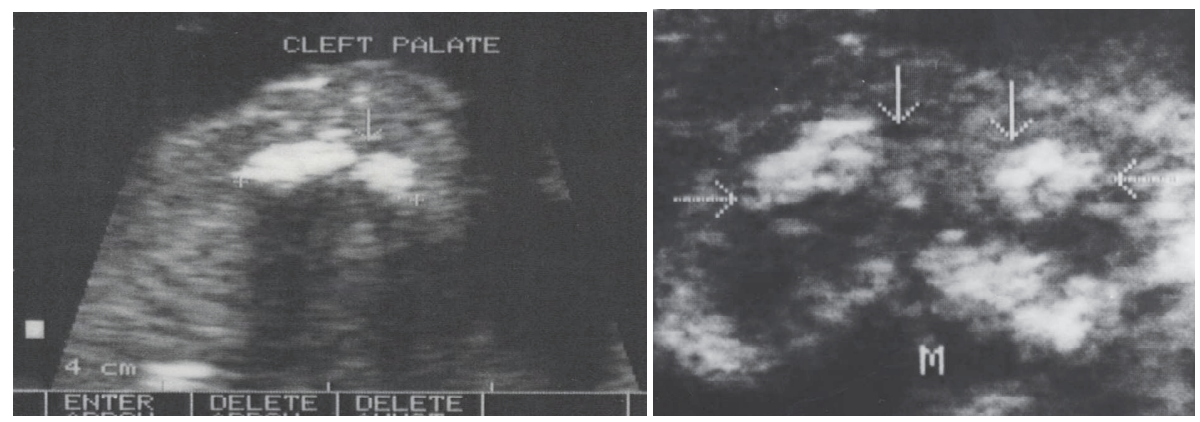

Fig. 14. Sonographic pictures of cleft palate ( $15 \& 23$ weeks of gestation)

\begin{tabular}{l|c|c}
\hline Gestation [weeks] & Mean $[\mathrm{mm}]$ & \pm SD $[\mathrm{mm}]$ \\
\hline $14-15$ & 10.5 & 1.3 \\
\hline 16 & 11.7 & 1.1 \\
\hline 17 & 16.6 & 2.5 \\
\hline 18 & 17.5 & 1.1 \\
\hline 19 & 18.0 & 1.1 \\
\hline 20 & 18.5 & 1.1 \\
\hline 21 & 18.5 & 2.1 \\
\hline 22 & 19.9 & 1.7 \\
\hline 23 & 20.5 & 1.9 \\
\hline 24 & 21.3 & 2.7 \\
\hline 25 & 22.8 & 1.9 \\
\hline 26 & 23.6 & 2.6 \\
\hline $27-28$ & 23.6 & 2.1 \\
\hline 30 & 25.5 & 2.2 \\
\hline 31 & 26.3 & 2.5 \\
\hline 32 & 26.5 & 2.1 \\
\hline
\end{tabular}

Table 16. Normal values of the fetal alveolar ridge width (Goldstein et al., 1999)

\section{The chin: Microganthia-retroganthia or prognathia}

Abnormal size of the chin, micrognathia and macrognathia, and abnormal length of the philtrum (short or long) are morphological features in numerous syndromes. Micrognathia is a common finding in many chromosome aberrations and dysmorphic syndromes (Gulla 
et al., 2005). Investigators have reported a series with subjective micrognathia, $66 \%$ of whom had chromosomal abnormalities (Nicolaides et al., 1993). Others reported that micrognathia was associated with aneuploidy in $25 \%$ and $38 \%$ of cases (Benacerraf et al., 1984; Turner \& Twining, 1993). Sivan et al. (1997) established normative dimensions for objective chin length. Measurements of the chin length, was performed between the lower lip and the apex of the chin in mid-sagittal plane.

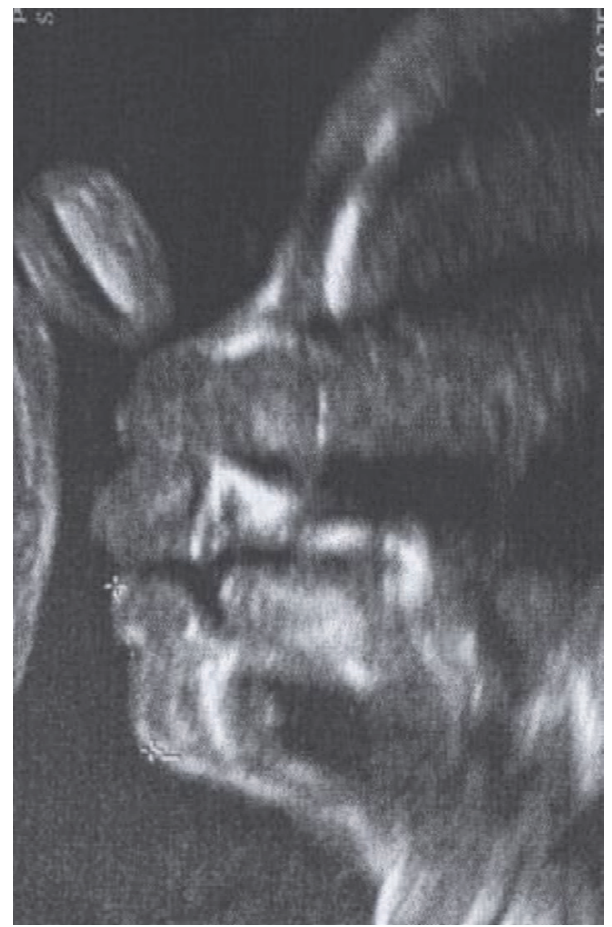

Fig. 15. Chin length measured between the lower lip and the apex of the chin (Sivan et al., 1977)

\begin{tabular}{|c|c|c|c|}
\hline GA & Mean & SD & Range \\
\hline Age (weeks) & $(\mathrm{mm})$ & & \\
\hline $16-17.9$ & 5 & 1 & $3-6$ \\
\hline $18-19.9$ & 7 & 1 & $6-9$ \\
\hline $20-21.9$ & 8 & 2 & $7-10$ \\
\hline $22-23.9$ & 10 & 1 & $9-11$ \\
\hline $24-25.9$ & 11 & 2 & $8-13$ \\
\hline $26-27.9$ & 11 & 2 & $9-12$ \\
\hline 28-29.9 & 13 & 2 & $11-15$ \\
\hline $30-31.9$ & 15 & 2 & $13-17$ \\
\hline $32-33.9$ & 18 & 2 & $16-20$ \\
\hline 34.35 .9 & 17 & 2 & $15-19$ \\
\hline $36-37.9 \quad 23$ & 1 & $22-24$ & \\
\hline
\end{tabular}

Table 17. Chin length (Sivan et al., 1997) 

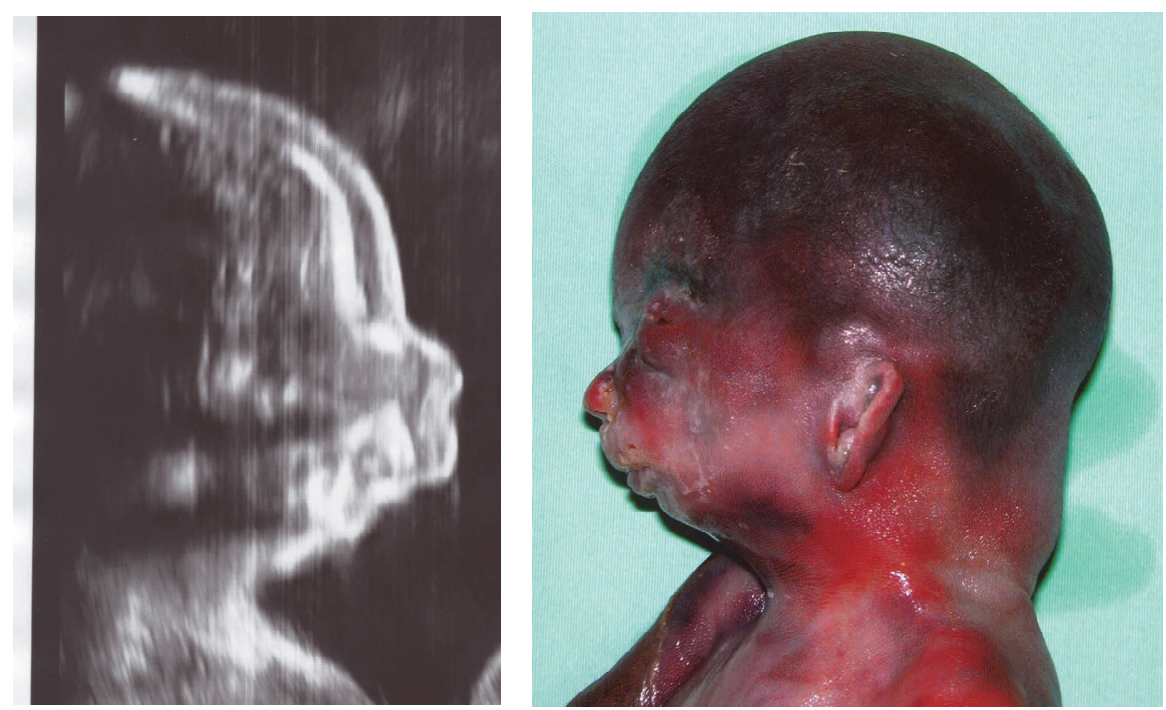

Fig. 16. Sagittal scan and postmortem of a fetus at 16 weeks of gestation shows prominent forehead and retrognathia

\section{References}

Arai, T. \& Kragic, D. (1999). Variability of Wind and Wind Power, In: Wind Power, S.M. Muyeen, (Ed.), 289-321, Scyio, ISBN 978-953-7619-81-7, Vukovar, Croatia

Lima, P.; Bonarini, A. \& Mataric, M. (2004). Application of Machine Learning, InTech, ISBN 978-953-7619-34-3, Vienna, Austria

Li, B.; Xu, Y. \& Choi, J. (1996). Applying Machine Learning Techniques, Proceedings of ASME 2010 4th International Conference on Energy Sustainability, pp. 14-17, ISBN 842-650823-3, Phoenix, Arizona, USA, May 17-22, 2010

Aase, J.M.; Wilson, A.C. \& Smith, D.W. (1973). Small ear in Downs' syndrome: a helpful diagnosis aid. Journal of Pediatrics, Vol.82, No.5, (May), pp. 845-847.

Achiron, R.; Ben Arie, A.; Gabbay, U.; Mashiach, S.; Rotstein, Z. \& Lipitz, S. (1997) Development of the fetal tongue between 14 and 26 weeks of gestation: in utero ultrasonographic measurements. Ultrasound in Obstetrics \& Gynecology, Vol. 9, No.1, (January), pp. 39-41.

Awwad, J.T.; Azar, G.B.; Karam, K.S. \& Nicolaides KH. (1994). Ear length: a potential sonographic marker for Down syndrome. International Journal of Gynaecology and Obstetrics, Vol.44, No. 3, (March), pp. 233-238.

Benacerraf, B.R. (1998). Ultrasound of fetal syndromes. Churchill Livingstone: New York, London, Philadelphia, San Francisco, pp. 83-223.

Benacerraf, B.R.; Frigoletto, F.D. Jr. \& Bieber, F.R. (1984). The fetal face: ultrasound examination. Radiology, Vol.153, No.2, (November), pp. 495-497.

Bergsma, D. (1979). Birth defects compendium. 2nd ed., Macmillan. 
Chen, M.; Wang, H.F.; Leung, T.Y.; Sahota, D.S.; Borenstein, M.; Nicolaides, K.; Lao, T.T. \& Lau, T.K. (2011). Frontomaxillary facial angle at $11+0$ to $13+6$ weeks in Chinese population. Journal of Maternal-Fetal and Neonatal Medicine, Vol.24, No.3 (March), pp. 498-501.

Chen, M.; Yang, X.; Leung, T.Y.; Sahota, D.S.; Fung, T.Y.; Chan, L.W.; Lao, T.T. \& Lau, T.K. (2009). Study on the applicability of frontomaxillary facial angle in the firsttrimester trisomy 21 fetuses in Chinese population. Prenatal Diagnosis, Vol.29, No.12, (December), pp. 1141-1144.

Chitkara, U.; Lee, L.; Oehlert, J.W.; Bloch, D.A.; Holbrook, R.H.; El-Sayed, Y.Y. \& Druzin, M.L. (2002). Fetal ear length measurement: a useful predictor of aneuploidy? Ultrasound in Obstetrics \& Gynecology, Vol.19, No.2, (February), pp. 131-135.

Cicero, S.; Curcio, P.; Papageorghiou, A.; Sonek, J. \& Nicolaides, K. (2001). Absence of nasal bone in fetuses with trisomy 21 at 11-14 weeks of gestation: an observational study. Lancet, Vol.358, No.9294, (November 17), pp. 1665-1667.

Crane, J.P.; LeFevre, M.L.; Winborn, R.C.; Evans, J.K.; Ewigman, B.G.; Bain, R.P.; Frigoletto, F.D. \& McNellis, D. (1994). A randomized trial of prenatal ultrasonographic screening: impact on the detection, management, and outcome of anomalous fetuses. The RADIUS Study Group. American Journal of Obstetrics and Gynecology, Vol.171, No.2 (August), pp. 392-399.

Cuick, W.; Provenzano, L.; Sullvan, C.A.; Gallousis, F.M. \& Rodis, J. (2004). Fetal nasal bone length in euploid and aneuploid fetuses between 11 and 20 weeks' gestation. A prospective study. Journal of Ultrasound in Medicine, Vol.23, No.10, (October), pp. 1327-1333.

Goldstein I., Jakobi P., Tamir A., \& Goldstick O. (1999). Nomogram of the fetal alveolar ridge: a possible screening tool for the detection of primary cleft palate. Ultrasound in Obstetrics \& Gynecology, Vol.14, No. 5, (November), pp. 333-337.

Goldstein I., Reece E.A., Gianluigi P., O'Connor T.Z., Lockwood C.J. \& Hobbins J.C. (1988). Sonographic assessment of the fetal frontal lobe: A potential tool for prenatal diagnosis of microcephaly. American Journal of Obstetrics \& Gynecology, Vol.158, No. 5, (May), pp. 1057-1062.

Goldstein I., Reiss A., Rajamim B.S. \& Tamir A. (2005). Nomogram of maxillary bone length in normal pregnancies. Journal of Ultrasound in Medicine, Vol.24, No.9, (September), pp. 1229-1233.

Goldstein I., Tamir A., Itskovitz-Eldor J. \& Zimmer E.Z. (1997). Growth of the fetal nose width and nostril distance in normal pregnancies. Ultrasound in Obstetrics $\mathcal{E}$ Gynecology, Vol. 9, No.1, (January), pp. 35-38.

Goldstein I., Tamir A., Weiner Z. \& Jakobi P. (2010). Dimensions of the fetal facial profile in normal pregnancy. Ultrasound in Obstetrics \& Gynecology, Vol.35, No.2, (February), pp. 191-194.

Goldstein I., Tamir A., Zimmer E.Z.\& Itskovitz-Eldor J. (1998). Growth of the fetal orbit and lens in normal pregnancies. Ultrasound in Obstetrics \& Gynecology, Vol. 12, No.3, pp. 175-179. 
Goldstein I., Weissman A., Brill-Zamir R., Laevsky I. \& Drugan A. (2003). Ethmocephaly caused by de novo translocation 18; 21 - prenatal diagnosis. Prenatal Diagnosis, Vol.23; No.10, (October), pp. 788-790.

Guis F., Vill Y., Vincent Y., Doumerc S., Pons J.C. \& Frydman R. (1995). Ultrasound evaluation of the length of the fetal nasal bones throughout gestation. Ultrasound in Obstetric Gynecology, Vol.5, No.5, (May), pp. 304-307.

Gull I., Wolman I., Merlob P.,Jaffa A.J., Lessing J.B. \& Yaron Y. (2005). Nomograms for the sonographic measurement of the fetal philtrum and chin. Fetal Diagnosis and Therapy, Vol.20, No. 2 (March-April), pp. 127-131.

Jeanty P., Cantraine F., Consaert E., Romero R. \& Hobbins J.C. (1984). The binocular distance: A new way to estimate fetal age. Journal of Ultrasound in Medicine; Vol.3, No.6, (June), pp. 241-243.

Johnson, D.D.; Pretorius, D.H.; Budorick, N.E.; Jones, M.C.; Lou, K.V.; James, G.M. \& Nelson, T.R. (2000). Fetal lip and primary palate: three-dimensional versus twodimensional US. Radiology, Vol.217, No.1, (October), pp. 236-239.

Lettieri L., Rodis J.F., Vintzileos A.M., Feeney L., Ciarleglio .L \& Craffey A. (1993). Ear length in second-trimester aneuploid fetuses. Obstetrics and Gynecology, Vol.18, No. 1, (January), pp. 57-60.

Mayden K.L., Totora M., Berkowitz R.L., Bracken M. \& Hobbins J.C. (1982). Orbital diameters: a new parameter for prenatal diagnosis and dating. American Journal of Obstetrics \& Gynecology, Vol.1;144 No.3, (October), pp. 289-297.

McGahan J.P., Nyberg D.A. \& Mack L.A. (1990). Sonography of facial features of alobar and semilobar holoprosecephaly American Journal of Roentgenol, Vol.154, No.1, (January), pp. 143-148.

Nicolaides K.H., Salvesen D.R., Snijders R.J. \& Gosden C.M. (1993). Fetal facial defects. Associated malformations and chromosomal abnormaties. Fetal Diagnosis and Therapy, Vol.8, No.1, (January-February) pp.1-9.

Pilu G., Reece R.A., Romero R., Bovicelli L. \& Hobbis J.C. (1986). Prenatal diagnosis of craniofacial malformations with ultrasonography. American Journal of Obstetrics $\mathcal{E}$ Gynecology, Vol.155; No.1, (July), pp. 45-50.

Shimizu T., Salvador L., Hughes-Benzie R., Dawson L., Nimrod C. \& Allanson J. (1977). The role of reduced ear size in the prenatal detection of chromosomal abnormalities. Prenatal Diagnosis, Vol.17, No.6, (June), pp. 545-549.

Sivan E., Chan L., Mallozzi-Eberle A. \& Reece E.A. (1997). Sonographic imaging of the fetal face and the establishment of normative dimensions for chin length and upper lip width. American Journal of Perinatology, Vol.14, No. 4, (April), pp. 191194.

Sivri D., Dane C., Dane B., Cetin A. \& Yayla M. (2006) Nomogram of fetal nasal bone length at 11-13 gestational weeks in fetuses. Perinatal Journal, Vol.14, No.3, (September), pp.

Smith D. \& Jones K.L. (1988). Smith's recognizable patterns of human malformation, $4^{\text {th }}$ ed. Philadelphia, WB Saunders Company.

Turner G.M. \& Twining P. (1993) The facial profile in the diagnosis of fetal abnormalities. Clinical Radiology, Vol.47, No.6 (June), pp. 389-95. 
Yeo L., Guzman E.R., Day-Salvatore D., Vintzileos A.M. \& Walters C. (1998). Prenatal detection of fetal aneuploidy using sonographic ear length. American Journal of Obstetrics \& Gynecology, Vol.178:S141. 


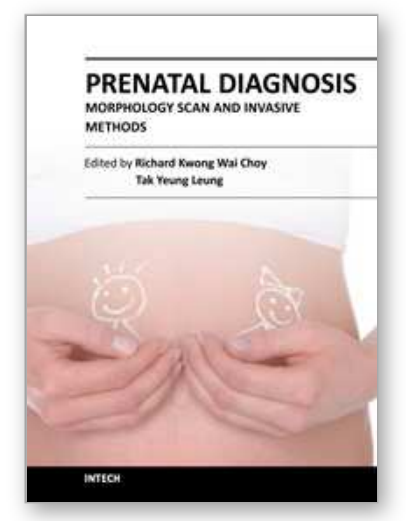

\author{
Prenatal Diagnosis - Morphology Scan and Invasive Methods \\ Edited by Dr. Richard Choy
}

ISBN 978-953-51-0614-2

Hard cover, 210 pages

Publisher InTech

Published online 29, June, 2012

Published in print edition June, 2012

This book provides detailed and comprehensive coverage on various aspects of prenatal diagnosis-with particular emphasis on sonographic and molecular diagnostic issues. It features sections dedicated to fundamentals of clinical, ultrasound and genetics diagnosis of human diseases, as well as current and future health strategies related to prenatal diagnosis. This book highlights the importance of utilizing fetal ultrasound/clinical/genetics knowledge to promote and achieve optimal health in fetal medicine. It will be a very useful resource to practitioners and scientists in fetal medicine.

\title{
How to reference
}

In order to correctly reference this scholarly work, feel free to copy and paste the following:

Israel Goldstein and Zeev Wiener (2012). Normal and Abnormal Fetal Face, Prenatal Diagnosis - Morphology Scan and Invasive Methods, Dr. Richard Choy (Ed.), ISBN: 978-953-51-0614-2, InTech, Available from: http://www.intechopen.com/books/prenatal-diagnosis-morphology-scan-and-invasive-methods/normal-andabnormal-fetal-face

\section{INTECH}

open science | open minds

\section{InTech Europe}

University Campus STeP Ri

Slavka Krautzeka 83/A

51000 Rijeka, Croatia

Phone: +385 (51) 770447

Fax: +385 (51) 686166

www.intechopen.com

\section{InTech China}

Unit 405, Office Block, Hotel Equatorial Shanghai

No.65, Yan An Road (West), Shanghai, 200040, China

中国上海市延安西路65号上海国际贵都大饭店办公楼 405 单元

Phone: +86-21-62489820

Fax: +86-21-62489821 
(C) 2012 The Author(s). Licensee IntechOpen. This is an open access article distributed under the terms of the Creative Commons Attribution 3.0 License, which permits unrestricted use, distribution, and reproduction in any medium, provided the original work is properly cited. 